\title{
Potentials and Challenges of Agricultural Education in reducing Postharvest losses (PHLs) and Food Insecurity in Ogun State, Nigeria
}

\author{
Oyediran, Wasiu Oyeleke ${ }^{1}$, Omoare, Ayodeji Motunrayo ${ }^{2}$ \\ ${ }^{1}$ Department of Agricultural Extension and Rural Development, Federal University of Agriculture \\ Abeokuta, Nigeria \\ ${ }^{2}$ Department of Agricultural Science Education, Federal College of Education, Abeokuta, Ogun State, Nigeria \\ oyediran_wasiu@yahoo.com
}

Abstract: Postharvest losses (PHLs) and food insecurity are major threats to agricultural growth and development in Nigeria. The challenges are enormous, especially in rural areas where food insecurity, poverty and educational deprivation often create a vicious circle. Therefore, this study was carried out to assess the potentials and challenges of Agricultural Education in reducing PHLs and food insecurity in Ogun State, Nigeria. One hundred and twenty-five (125) respondents were selected as sample size using simple random sampling technique. Data obtained were analyzed with descriptive statistics and chi-square. Results showed that majority of the respondents acquired knowledge of Crop Production and Management (83.20\%), Cassava processing (48.00\%), Poultry (57.60\%), and fish production skills (41.60\%). In the same vein, Agricultural Education has been identified as important driven force to reduce PHLs $(\overline{\mathrm{X}}=4.22$; SD $=1.18)$ and facilitate quality farm products and its availability all the year-round $(\overline{\mathrm{X}}=4.16$; $\mathrm{SD}=0.92)$. Results of chi-square showed a significant relationship between the skill acquisition $(\chi 2=13.26, \mathrm{df}=1)$ and perception of the respondents on Agricultural Education at $\mathrm{p}<0.05$ level of significance. However, effective Agricultural Education teaching and learning process was constrained by inadequate resource personnel $(\mathrm{t}=-2.492)$, epileptic power supply $(\mathrm{t}=2.233)$, poor funding of agricultural education $(t=2.525)$, inadequate agricultural instructional materials $(t=2.286)$, poor support for agricultural researches and findings $(t=6.643)$, inadequate functional processing facilities $(t=-4.543)$ at $p<0.05$ level of significance. This study concluded that Agricultural Education contributed to skill acquisition in agricultural production and food security.

Keywords: agriculture, education, potentials, challenges, postharvest losses, food insecurity.

\section{INTRODUCTION}

The world population is increasing faster than the growth in the food supply, and the resources used for creating food are all becoming increasingly scarce. Reducing postharvest food losses must be an essential component in any strategy to make more food available without increasing the burden on the natural environment (World Bank, 2010). Nigeria is agrarian, and agriculture remains the hub of the rural Nigerians, providing employment for over 90 percent of the rural dwellers, who constitute about 70 percent of the total population. Nigeria's strengths include abundant land, labour, and natural resources (Ayodele et al., 2013). Postharvest losses (PHLs) and food insecurity are major threats to agricultural growth and development in Nigeria. The challenges are enormous, especially in rural areas where food insecurity, poverty and educational deprivation often create a vicious circle. The issue in Nigeria is inefficient postharvest agricultural systems that lead to a loss of food that people would otherwise eat, sell or barter to improve their livelihoods. As a product moves in the postharvest chain, food wastages may occur from a number of causes, such as from improper handling or bio-deterioration 
by micro-organisms, insects, rodents or birds. Developed countries have extensive and effective cold chain systems to prolong product shelf-life. Additionally, more sophisticated management and new technologies continue to improve the efficiency with which food is brought into stores, displayed and sold. Computerized stock control has dramatically decreased the volume of stock held within the food chain, driving down costs (Houghton and Portougal, 1997). Traditional agricultural practices prevail in Nigeria at subsistence level while rural infrastructures are grossly inadequate and as such contributed to high PHLs in the country. Climbing out of these prolonged problems cannot be achieved by addressing one sector alone. It is therefore essential to explore feasible measures in which these inter-related issues can be tackled together, focusing on interventions which have the greatest effect on food security and PHLs reduction. Basic education initiatives in rural areas which will use agricultural or environmental experience as a means of making teaching and learning more relevant and the potential impact of this kind of approach on food security and sustainable rural development are very germane. The food system is a heavy component of the human environmental footprint on the planet. Advancement and sustainable development is a very vital issue in a global world. Agriculture is a reliable source of food, income, raw materials and employment across the world and sub-Saharan Africa in particular. Among the most important and efficient ways to improve food security, nutrition, and income for millions of small scale farmers in Nigeria, is to make sure that every bulk of vegetable, baskets of tomatoes, or kilogram of grains that is produced is stored properly and delivered in good condition from farm to table. It is very important to ensure that goods produced are well packaged, marketed and that they reach consumers in good condition. It's high time to make solving the problems of food and nutrition insecurity and PHLs a thing of the past.

In line with these objectives Agricultural Education is focused on acquisition of individual skills and capability for occupation; therefore Agricultural Education is both theoretical and practical in its design and it is packaged to provide knowledge and develop the skills of the future youths for sustainable development. This is capable of eliminating poor agricultural practices, PHLs, food insecurity and low income in the rural areas of Nigeria. Agricultural Education has been an integral part of national development strategies because of the impact on human resources development, productivity and economic growth. It is a vital tool to economic development, enterprise productivity and profitability, national productivity and wealth creation, and for individual prosperity. Moseri (2000) commented that the conditions for an effective agricultural development include a high average educational attempt, adequate capital, quantity and quality of land and technology, development of quality production skills, formation of agricultural associations and supporting services, facilities and programmes. Although Agricultural Education has enormous potentials in checking high rate of PHLs and food insecurity in Nigeria, the sector has not been given much attention by the government. Similarly, there are scanty empirical studies on the inter-relationship of Agricultural Education, PHLs and food insecurity.

The situation of high PHLs and food insecurity called for education of citizenry on proper food management. Adopting this approach and the opportunities it presents can lead to greater systemic efficiency, food safety and quality. It is in against this background that this study assessed the perception of students in selected tertiary institutions on potentials and challenges of Agricultural Education in reducing PHLs and food insecurity in Ogun State, Nigeria.

\section{Specific Objectives are to}

i. identify the skill acquisition by the students through Agricultural Education in the study area

ii. assess perception of the students on Agricultural Education as a means of reducing PHLs and food insecurity in the study area

iii. identify constraints to effective Agricultural Education in reducing PHLs and food insecurity in the study area 


\section{Hypotheses}

H01: There is no significant association between the skill acquired by the respondents and perception of the respondents on Agricultural Education as a means of reducing PHLs and food insecurity in the study area.

H02: Challenges to Agricultural Education have no significant influence on its contributions to the skill acquisition in reducing PHLs and food insecurity in the study area

\section{METHODOLOGY}

\section{Description of study area}

The study was carried out in Ogun State, Nigeria. Odeda and Ijebu-Ode Local Government Areas were purposively selected. The two Local Government Areas are parts of the twenty LGAs in Ogun State that have large numbers of rural dwellers who engaged in farming activities as means of livelihoods. There are also two tertiary institutions in each of the two LGAs. In Odeda LGA, there are two Federal institutions namely: Federal College of Education, Abeokuta (FCE) and Federal University of Agriculture, Abeokuta (FUNAAB) while Ijebu-Ode LGA has Tai Solarin College of Education (TASCE), Omu and Tai Solarin University of Education (TASUED), Ijagun, Ogun State, Nigeria. These institutions train and empower youths in diverse fields of agriculture. The Federal College of Education, Abeokuta provides three-year full-time and five-year sandwich courses respectively leading to the award of the Nigeria Certificate in Education (NCE). The Federal University of Agriculture, Abeokuta (FUNAAB) is one of the three Universities of Agriculture in Nigeria, the others being in Markudi, Benue State and Umudike, Abia State which were established in January, 1988. FUNAAB has a land mass of 10,000ha. There are 179 academic programmes made up of 44 undergraduate programmes, 22 Post Graduate Diploma (PGD), 57 Masters' degree programmes and 56 Doctorate degree programmes (www.unaab.edu.ng).

\section{Sampling Techniques and Sample Size}

Departments of Agricultural Education were selected from Federal College of Education, Osiele (FCE), Tai Solarin College of Education (TASCE), Omu and Tai Solarin University of Education (TASUED), Ijagun while Community Based Framing System (COBFAS) unit was selected from Federal University of Agriculture, Abeokuta (FUNAAB). There are 79 final year students in Agricultural Education Department, FCE and 287 students in the selected section of COBFAS, 53 students in Agricultural Education Department, TASCE and 80 students in Agricultural Education Department of TASUED. Proportional sampling technique was used to select $25 \%$ of the students (i.e. 20 from FCE, 72 from FUNAAB, 13 from TASCE and 20 from TASUED) to make up 125 respondents as sample size for this study. Data for this study were collected with the aid of questionnaire and analyzed using SPSS software. The questionnaire was subjected to face validity by consulting experts in the fields of Agricultural Extension and Rural Development. Items found ambiguous and lacking in clarity were eliminated. Test re-test was carried out at interval of two weeks with fifteen (15) Agricultural students in Emmanuel Alayande College of Education, Lanlate Campus, Oyo State to ascertain the reliability of the instrument. Total scores were computed for each week and analyzed with Pearson Product Moment Correlation (PPMC) to get correlation coefficient (r) between two sets of scores. A reliability coefficient of 0.83 was obtained hence, the instrument was termed reliable.

\section{Measurement of Variables}

Skills acquisition through Agricultural Education was measured on a 3-point indicator of greatly acquired, somehow acquired and not-acquired. The perception of the respondents on agricultural education as a means of reducing PHLs and food insecurity was measured using Likert scale type of Strongly Agree (5), Agree (4), Undecided (3), Disagree (2), and Strongly Disagree (1). The statements are self-worded in both positive and 
negative forms to avoid bias, whereas the scores are reversed for the negative statements. The mean and standard deviation were estimated. Challenges to Agricultural Education were ranked by the respondents.

\section{Method of Data Analysis}

Data collected for this study were subjected to descriptive statistics such as percentage, mean and frequency distribution while linear regression and chi-square analysis were used to test the hypotheses. For the linear regression in this study, it is expressed as

$\mathrm{E}=\mathrm{f}(\mathrm{c})+\mathrm{ei}$

Where;

$\mathrm{E}=$ Agricultural Education (aggregate scores)

$\mathrm{c}=$ Challenges (aggregate scores)

ei $=$ error term

\section{RESULTS AND DISCUSSION}

\section{Skills acquisition through Agricultural Education}

According to the National policy of Nigeria (FGN, 2004), the philosophy of education is based upon a strong, united and self-reliant nation. Above eighty percent (83.20\%) of the respondents greatly acquired skills in Crop Production and Management while $48.00 \%$ of the respondents got skills in Cassava processing in the institutions. The implication is that the skills acquired will help to accelerate food production by the youth and minimize postharvest losses through proper handling. This is in conformity with Ofoh, 2009 who stated that agro-processing is an important operation to reduce spoilage, waste and other losses in quantity and quality of farm produce between the time of harvesting and time of marketing/consumption. Also, 57.60\% of the respondents acquired skills in Poultry production and $41.60 \%$ in Catfish and Tilapia production. This will go a long way to assist in producing high quality poultry and fish products in the study area as these skills will facilitate rapid job creation, self-empowerment, increased production and household food security. Similarly, more than half (51.20\%) of the respondents had greatly acquired skills in agricultural extension practice. This is the hallmark of agricultural activities that involve continuous training and dissemination of innovation to the farmers with the aim of transforming agriculture and improving farmers' standard of living. This means that the students can use skills acquired to establish their own small/medium scale agricultural enterprises and become employers of labour. These knowledge and skills acquisition are very important potentials upon which Agricultural Education is built in Nigeria. However, students were unable to acquire much skill in palm oil processing $(22.20 \%)$. This situation cannot be unconnected with the inadequate palm-oil processing machines in the institutions.

Table1. Distribution based on skills acquired through Agricultural Education ( $n=125)$

\begin{tabular}{|l|l|l|l|l|}
\hline S/N & Skills acquired through Agricultural Education & GA & SA & NA \\
\hline 1. & Crop Production and Management skill & 83.20 & 13.60 & 3.20 \\
\hline 2. & Quality cassava processing to various products & 48.00 & 39.20 & 12.80 \\
\hline 3. & Poultry Production skill & 57.60 & 32.80 & 9.60 \\
\hline 4. & Catfish and Tilapia Production skill & 41.60 & 29.60 & 28.80 \\
\hline 5. & Palm oil processing skill & 22.40 & 32.80 & 44.80 \\
\hline 6. & Agricultural Extension Practices & 51.20 & 32.80 & 16.00 \\
\hline
\end{tabular}

Source: Field survey, 2014; GA - Greatly Acquired, SA - Somehow Acquired, NA - Not Acquired 
Perception of the respondents on Agricultural Education in reducing PHLs and food insecurity

Agricultural Education is utilitarian and stimulating bringing theoretical ideals to practical reality. Education and social marketing strategies that strengthen local food systems and promote cultivation and consumption of local micronutrient rich foods is very essential to overcome the twin problems of postharvest losses and food insecurity situation in Nigeria. In Table 2, the results showed that most (84.0\%) of the respondents strongly agreed that Agricultural Education will help youth in acquiring knowledge and skills in farming $(\overline{\mathrm{X}}=4.84$; S.D $=0.37$ ) while $12.8 \%$ of the respondents strongly disagreed that knowledge acquired may not be transferred to farmers in the rural areas $(\overline{\mathrm{X}}=3.97 ; \mathrm{S} . \mathrm{D}=0.99)$. The reason is that some graduates of agricultural discipline may not be willing to live in the rural areas because of the appalling state of infrastructural decay and neglect; hence they cannot have close contact with the farmers to disseminate innovation. Many (48.0\%) of the respondents strongly agreed that Agricultural Education will facilitate increased food production $(\overline{\mathrm{X}}=4.16$; S.D $=1.17)$, and promote youth development, job creation and empowerment $(\overline{\mathrm{X}}=4.74$; S.D $=0.51$ ) whereas $19.2 \%$ of the respondents strongly disagreed that it cannot provide jobs for rural people $(\overline{\mathrm{X}}=3.40$; S.D $=1.50)$. The argument against the huge potentials of Agricultural Education is not unconnected with the high rate of youth unemployment in Nigeria. Evidently, Nigeria is lagging behind in preparing her workforce for the challenges of the rapidly changing global economy (Adefiaye, 2004). Rising unemployment, lack of skilled workers, high dropout rates, and the changing demographic nature of the work force constituted impediments to economic growth and development in Nigeria. Eneji (2000) opined that Nigeria needs a major breakthrough in an attempt to come out of these abject poverty situations which have youths and graduates unemployment as major attributes. Moreover, $45.6 \%$ of the respondents strongly agreed that efficient farm management and record keeping is possible ( $\overline{\mathrm{X}}=3.84$; S.D $=1.11)$, and $48.8 \%$ of the respondents strongly agreed that rural-urban migration will be reduced ( $\overline{\mathrm{X}}=3.84 ; \mathrm{S} . \mathrm{D}=1.35)$. This is very possible because record keeping will minimize losses and make agriculture more profitable and attractive to the youths thereby encouraging them to do farming and stay in the rural areas instead of searching for white collar job in the Cities. The implication is that more food will be produced for the rural households and public. In a similar vein, $55.2 \%$ of the respondents strongly agreed that innovation dissemination and adoption could only be successful through agricultural extension $(\bar{X}=4.16$; S.D $=1.17)$. This implies that agricultural productivity will be high and young farmers will be motivated to stay on the farm. Agriculture will be repositioned from traditional to a modernized and commercial farming; fresh, nourished and safe food will be produced abundantly while surplus will be processed, packaged, and stored for further uses through Agricultural Extension support. Also, $59.2 \%$ and $52.8 \%$ of the respondents agreed that PHLs will be minimized through proper handling $(\overline{\mathrm{X}}=4.22 ; \mathrm{S} . \mathrm{D}=1.18)$ and quality farm products will be achieved $(\overline{\mathrm{X}}=4.25 ; \mathrm{S} . \mathrm{D}=0.89)$ respectively. Since modern methods of agricultural practices are parts of teaching in tertiary institutions, the skills acquired in postharvest technology will help to curb huge losses and poor pricing of agricultural produce. It will also help in ensuring quality products and extending the shelf-life of agricultural commodities. In a sharp contrast, $40.8 \%$ of the respondents also disagreed that Agricultural Education is for teaching sake and cannot guarantee increased food production $(\overline{\mathrm{X}}=3.20$; S.D $=1.49)$. The reaction is due to the fact that most of the agricultural students are exposed to practical aspects. Agricultural Education is a type of vocational training involving the equipping of the learners with the knowledge and skills involved in productive agriculture. It involves the training of both the head and the hands of the learners (Ekpenyong, 2005). The respondents also indicated that fresh and quality agricultural products will be made available in the markets all year round $(\bar{X}=4.16$; S.D $=0.92)$, farmers' income will increase $(\bar{X}=4.38$; S.D $=0.66)$, household nutrition and food security will be enhanced through 
increased farm production ( $\overline{\mathrm{X}}=4.00 ; \mathrm{S} . \mathrm{D}=1.08)$, and adult and mass literacy will be realized in the rural areas $(\overline{\mathrm{X}}=4.14 ; \mathrm{S} . \mathrm{D}=1.07)$ through Agricultural Education.

Table2. Perception of the respondents on Agricultural Education in reducing PHLs and food insecurity ( $n=125)$

\begin{tabular}{|l|l|l|l|l|l|l|l|}
\hline Statement & SA & A & U & D & SD & $\overline{\mathrm{X}}$ & S.D. \\
\hline $\begin{array}{l}\text { Agricultural Education will help youth in acquiring } \\
\text { knowledge and skills in farming }\end{array}$ & 84.0 & 16.0 & 0.0 & 0.0 & 0.0 & 4.84 & 0.39 \\
\hline $\begin{array}{l}\text { Knowledge acquired may not be transferred to farmers } \\
\text { in the rural areas* }\end{array}$ & 32.0 & 45.6 & 3.2 & 6.4 & 12.8 & 3.97 & 0.99 \\
\hline It will facilitate increased food production & 48.0 & 39.2 & 0.0 & 3.2 & 9.6 & 4.16 & 1.17 \\
\hline $\begin{array}{l}\text { It will promote youth development, job creation and } \\
\text { empowerment }\end{array}$ & 77.6 & 19.2 & 3.2 & 0.0 & 0.0 & 4.74 & 0.51 \\
\hline $\begin{array}{l}\text { Agricultural Education cannot provide jobs for rural } \\
\text { people* }\end{array}$ & 29.6 & 32.0 & 6.4 & 12.8 & 19.2 & 3.40 & 1.50 \\
\hline $\begin{array}{l}\text { Efficient farm management and record keeping is } \\
\text { possible }\end{array}$ & 45.6 & 28.8 & 2.4 & 10.4 & 12.8 & 3.84 & 1.11 \\
\hline Rural-urban migration will be reduced & 48.8 & 32.0 & 0.0 & 3.2 & 16.0 & 3.84 & 1.35 \\
\hline $\begin{array}{l}\text { Dissemination of improved production practices } \\
\text { through agricultural extension education }\end{array}$ & 55.2 & 35.2 & 0.0 & 9.6 & 0.0 & 4.16 & 1.17 \\
\hline PHLs will be minimized through proper handling & 59.2 & 32.8 & 0.0 & 0.0 & 8.0 & 4.22 & 1.18 \\
\hline Quality farm products will be achieved & 52.8 & 41.6 & 2.4 & 3.2 & 0.0 & 4.25 & 0.89 \\
\hline $\begin{array}{l}\text { Agricultural Education is for teaching sake and cannot } \\
\text { guarantee increased food production* }\end{array}$ & 16.0 & 17.6 & 0.0 & 22.4 & 40.8 & 3.20 & 1.49 \\
\hline $\begin{array}{l}\text { Fresh and quality agricultural products will be made } \\
\text { available in the markets all year round }\end{array}$ & 48.8 & 38.4 & 3.2 & 9.6 & 0.0 & 4.16 & 0.92 \\
\hline Farmers' income will increase & 52.0 & 44.8 & 5.6 & 0.0 & 0.0 & 4.38 & 0.66 \\
\hline $\begin{array}{l}\text { Household nutrition and food security will be enhanced } \\
\text { through increased farm production }\end{array}$ & 53.6 & 40.0 & 6.4 & 0.0 & 0.0 & 4.00 & 1.08 \\
\hline $\begin{array}{l}\text { Adult and mass literacy will be realized in the rural } \\
\text { areas through Agricultural Education }\end{array}$ & 49.6 & 33.6 & 10.4 & 6.4 & 0.0 & 4.14 & 1.07 \\
\hline
\end{tabular}

Source: Field survey, 2014. *Negative statement

SA - Strongly Agree, A - Agree, U - Undecided, D - Disagree, SD - Strongly Disagree, $\overline{\mathbf{X}}$ - Mean, and S.D. - Standard Deviation

\section{Challenges to Agricultural Education}

There are many challenges to Agricultural Education in Nigeria. Currently, Agricultural Education is being taught as one of the art subjects and given orientation as education for citizenship (Egbule, 2002). The results in Table 3 showed that inadequate resource personnel (71.20\%) was ranked 1st while epileptic power supply $(66.40 \%)$ ranked 2nd as a major challenges confronting Agricultural Education in tertiary institutions in the study area. The available Lecturers are over-stretched with too much load of work which is seriously affecting the efficiency of Agricultural Education delivery in the institutions. Epileptic power supply remains a national problem; it impeded the rate of skill acquisition in agriculture because most the machines use during practical classes are power driven. Poor funding of agricultural education (64.8\%) was ranked 3rd and it creates a serious vacuum in agricultural development of the nation. Inadequate agricultural instructional materials (60.8\%) and 
support for agricultural researches and findings (57.0\%) were ranked as 4th and 5th as major constraints to Agricultural Education in the study area. This result corroborates with that of Yussuf and Soyemi (2012), that problem of low quality training among vocational students is alarming because of inadequate instructional materials. Also, too short time allocating for the practical session (55.2\%) constituted the 6th major impediment to the transfer of knowledge and skills to the students. Hence, emphasis is much on theory and certification rather than skill acquisition and proficiency training. Similarly, respondents identified inadequate functional processing facilities (53.6\%), poor maintenance of infrastructure $(51.20 \%)$ and poor learning environment (44.0\%) as major challenges inhibiting Agricultural Education in the study area. The implication of this is that the students will not be able to acquire skill under poor study condition and it will have bearing on the skill acquisition which is the primary objective of Agricultural Education in our tertiary institutions. The problems will have a multiply effect on food production, handling and quality therefore contributing to poor productivity, and high PHLs.

Table4. Distribution based on challenges to agricultural education ( $n=125)$

\begin{tabular}{|l|l|l|l|l|l|}
\hline S/N & Challenges & $\begin{array}{l}\text { Extremely } \\
\text { serious }\end{array}$ & $\begin{array}{l}\text { Moderately } \\
\text { serious }\end{array}$ & $\begin{array}{l}\text { L e S S } \\
\text { serious }\end{array}$ & Rank \\
\hline 1. & Inadequate resource personnel & 71.20 & 22.40 & 6.40 & $1^{\text {st }}$ \\
\hline 2. & Inadequate functional processing facilities & 53.60 & 40.00 & 6.40 & $7^{\text {th }}$ \\
\hline 3. & Epileptic power supply & 66.40 & 22.40 & 11.20 & $2^{\text {nd }}$ \\
\hline 4. & Poor maintenance of infrastructure & 51.20 & 39.20 & 9.60 & $8^{\text {th }}$ \\
\hline 5. & $\begin{array}{l}\text { Too short time allocating for the practical } \\
\text { session }\end{array}$ & 55.20 & 28.80 & 16.00 & $6^{\text {th }}$ \\
\hline 6. & $\begin{array}{l}\text { Inadequate agricultural instructional } \\
\text { materials }\end{array}$ & 60.80 & 26.40 & 12.80 & $4^{\text {th }}$ \\
\hline 7. & Poor funding of agricultural education & 64.80 & 28.80 & 6.40 & $3^{\text {rd }}$ \\
\hline 8. & $\begin{array}{l}\text { Inadequate support for agricultural researches } \\
\text { and findings }\end{array}$ & 57.00 & 36.00 & 6.40 & $5^{\text {th }}$ \\
\hline 9. & Poor learning environment & 44.00 & 32.00 & 24.00 & $9^{\text {th }}$ \\
\hline
\end{tabular}

Source: Field survey, 2014

\section{TEST OF HYPOTHESES}

\section{Association between skill acquisition and PHLs and food insecurity}

H01: There is no significant association between the skill acquired by the respondents and perception of the respondents on Agricultural Education as a means of reducing PHLs and food insecurity in the study area.

The results of chi-square analysis in Table 4 showed a significant relationship between the skill acquisition and perception of the respondents on Agricultural Education at $p<0.05$ level of Agricultural Education. Skills acquired in quality cassava processing $(\chi 2=13.26, \mathrm{df}=1)$, poultry production $(\chi 2=17.42, \mathrm{df}=1)$ and agricultural extension practices $(\chi 2=8.98, \mathrm{df}=1)$ were significant to Agricultural Education for reducing PHLs and food insecurity at $\mathrm{p}<0.05$ level. This relationship can be inferred from the fact that students are often exposed to many of these courses through their staying in the institutions. Meanwhile, skills acquisition in crop production and protection $(\chi 2=1.73, \mathrm{df}=1)$, Catfish and Tilapia production $(\chi 2=4.44, \mathrm{df}=1)$ and palm-oil processing $(\chi 2=2.74, \mathrm{df}=1)$ were not significant at $\mathrm{p}<0.05$ level of significance. This can be as a result of shortcomings in these fields which call for urgent intervention in order to increase agricultural productivity and minimize 


\section{American Research Journal of Agriculture (ARJA)}

losses. Thus, the alternate hypothesis (H1) that "there is significant association between the skill acquired by the respondents and perception of the respondents on Agricultural Education as a means of reducing PHLs and food insecurity" is accepted.

Table4. Association between skill acquisition and PHLs and food insecurity

\begin{tabular}{|l|l|l|l|l|}
\hline Skills acquired through Agricultural Education & $\chi^{2}$ & df & p-value & Decision \\
\hline Agricultural Extension Practices & 8.94 & 2 & 0.01 & S \\
\hline Crop Production and Management skill & 1.73 & 2 & 0.42 & NS \\
\hline Quality cassava processing to various products & 13.26 & 3 & 0.01 & S \\
\hline Poultry Production skill & 17.42 & 2 & 0.00 & S \\
\hline Catfish and Tilapia Production skill & 4.44 & 3 & 0.22 & NS \\
\hline Palm oil processing skill & 2.74 & 2 & 0.25 & NS \\
\hline Agricultural Extension Practices & 8.94 & 2 & 0.01 & S \\
\hline
\end{tabular}

Source: Field survey, 2014

$\mathrm{S}$ - Significant at $\mathrm{p} \leq 0.05$

NS - Not Significant at $\mathrm{p} \leq 0.05$

Relationship between Challenges and Agricultural Education for reducing PHLs and food insecurity

H02: Challenges to Agricultural Education have no significant influence on its contributions to the skill acquisition in reducing PHLs and food insecurity in the study area.

Results indicated that challenges had a significant bearing on Agricultural Education in Nigeria. Challenges such as inadequate resource personnel $(t=-2.492)$, epileptic power supply $(t=2.233)$, poor funding of agricultural education $(t=2.525)$, inadequate agricultural instructional materials $(t=2.286)$, poor support for agricultural researches and findings $(t=6.643)$, inadequate functional processing facilities $(t=-4.543)$, and poor learning environment $(\mathrm{t}=-3.551)$ were significant to Agricultural Education for reducing PHLs and food insecurity at $\mathrm{p}<0.05$ level of significance. The more severe the problems confronting Agricultural Education, the lesser the rate at which knowledge and skills will be transmitted and acquired through Agricultural Education. Consequently, agricultural productivity will be retarded and problems of PHLs and food insecurity will be heightened. The alternate hypothesis (H1) that "challenges to Agricultural Education have significant influence on its contributions to the skill acquisition in reducing PHLs and food insecurity" is hereby accepted.

Table5. Relationship between Challenges and Agricultural Education for reducing PHLs and food insecurity

\begin{tabular}{|l|l|l|l|l|l|}
\hline Variables & \multicolumn{2}{|l|}{$\begin{array}{l}\text { Unstandardized } \\
\text { Coefficient }\end{array}$} & $\begin{array}{l}\text { Standardized } \\
\text { Coefficient }\end{array}$ & $\mathrm{t}$ & Significance \\
\hline & $\beta$ & Std. Error & Beta & & \\
\hline Constant & 48.908 & 3.230 & & 15.142 & 0.000 \\
\hline Inadequate resource personnel & -1.958 & 0.786 & -0.200 & -2.492 & $0.014^{*}$ \\
\hline Inadequate functional processing facilities & -4.714 & 1.038 & -0.484 & -4.543 & $0.000^{*}$ \\
\hline Epileptic power supply & 1.593 & 0.723 & 0.210 & 2.233 & $0.042^{*}$ \\
\hline Poor maintenance of infrastructure & 0.970 & 0.755 & 0.110 & 1.285 & $0.202 \mathrm{NS}$ \\
\hline $\begin{array}{l}\text { Too short time allocating for the practical } \\
\text { session }\end{array}$ & 0.953 & 0.727 & 0.109 & 1.310 & $0.193 \mathrm{NS}$ \\
\hline
\end{tabular}


American Research Journal of Agriculture (ARJA)

\begin{tabular}{|l|l|l|l|l|l|}
\hline $\begin{array}{l}\text { Inadequate agricultural instructional } \\
\text { materials }\end{array}$ & 1.961 & 0.858 & 0.231 & 2.286 & $0.024^{*}$ \\
\hline Poor funding of agricultural education & 2.111 & 0.836 & 0.220 & 2.525 & $0.013^{*}$ \\
\hline $\begin{array}{l}\text { Inadequate support for agricultural } \\
\text { researches and findings }\end{array}$ & 7.201 & 1.084 & 0.759 & 6.643 & $0.000^{*}$ \\
\hline Poor learning environment & -3.114 & 0.877 & -0.440 & -3.551 & $0.001^{*}$ \\
\hline Test of Fitness & & & & & \\
\hline F - statistics & 8.928 & & & & \\
\hline $\mathrm{R}^{2}$ & 41.1 & & & & \\
\hline Adjusted R & 36.5 & & & & \\
\hline Durbin-Watson & 1.863 & & & & \\
\hline Prob(F-Statistics) & 0.000 & & & & \\
\hline
\end{tabular}

Source: Field survey, 2014

*- Significant at $\mathrm{p} \leq 0.05$

NS - Not Significant at $\mathrm{p}>0.05$

\section{CONCLUSION}

The study concludes that skills acquisition in Crop Production and Management, Cassava processing, Poultry production, and Catfish and Tilapia production could have a great contributions to reducing PHLs and food insecurity. The respondents strongly agreed that Agricultural Education would reduce PHLs and facilitate quality farm products and its availability all the year-round. Also, a significant association existed between the skills acquisition and perception of the respondents on agricultural education as a means of reducing PHLs and food insecurity in the study area. However, objectives of Agricultural Education were affected by myriad of problems such as inadequate resource personnel, epileptic power supply, poor funding of Agricultural Education and inadequate instructional materials among others.

\section{RECOMMENDATIONS}

Based on the finding of this study, the following recommendations were suggested to improve the Agricultural Education in order to minimize postharvest losses and food insecurity in the study area:

1. The rural infrastructure most importantly the electricity, processing and storage facility should be improved on if substantive reduction in PHLs and food insecurity could be achieved.

2. Agricultural Education should be accorded a priority by adequate funding of the researches and findings that can lead to increased food production, better postharvest handlings and food security in the study area.

3. Agricultural Education should be adequately supported and promoted by the government at all levels. Agricultural Education will accelerate knowledge and skill acquisition by the youth and it will have multiplier effect on food production and productivity as well as youth empowerment in the study area.

4. Private organizations and donors should support government by providing conducive learning environment and supporting capacity building and skill acquisition of youth in various agriculture enterprises as this will go a long way to make youth self-reliant, minimize youth unemployment and restiveness in the study area and Nigeria at large.

5. Also, problems of staffing should be looked into by the concern authority in order not to over-stretch the available workers. 


\section{REFERENCES}

Adefiaye, G. (2004). Neglect of technical, vocational education increase both unemployment. Don., Vanguard, Lagos, Nigeria, 30p.

Ayodele, O. S., Obafemi, F. N. and Ebong, F. S. (2013). Challenges facing the achievement of the Nigeria vision. Global Advanced Research Journal of Social Sciences, 27, 143-157.

Egbule, P. E. (2002). Fundamentals and Practices of Agricultural Education. Owerri: Totan.

Ekpenyong, L. E. (2005). Foundations of Technical and Vocational Education; Evolution and Practice. Benin. Ambik Press Limited.

Eneji, S. C. O. A. (2000). The Politics of Poverty Alleviation Initiatives in Nigeria (A Lead Paper delivered at the 2000 Annual Conference of the Nigerian Educational Research Association at University of Nigeria, Nsukka.

Federal Government of Nigeria, (2004). National Policy on Education. Lagos: NERDC Press.

Federal University of Agriculture, Abeokuta (FUNAAB). www.unaab.edu.ng.

Houghton, E. and Portougal, V. (1997). Reengineering the production planning process in the food industry. International Journal of Production Economics 50, 105-116

Moseri, B. (2000). Modem Issues in Crop Production and Management. Agbor: Krisbec Publication.

Ofoh, M. C. (2009). Food security and mitigation of climate change through Ecosystem based Agriculture, 13th inaugural lecture of the Federal University of Technology Owerri (FUTO), Imo State, p. 24.

World Bank, (2010). Missing Food: The Case of Postharvest Grain Losses in Sub-Saharan Africa. Washington, D. C. The World Bank.

Yusuff, M. A. and Soyemi, J. (2012). Achieving Sustainable Economic Development in Nigeria through Technical and Vocational Educational and Training. The Missing Lenics. International Journal of Academic Research in Business and Social Sciences, 2 (2), 71-77.

Citation: Oyediran, Wasiu Oyeleke, Omoare, Ayodeji Motunrayo, "Potentials and Challenges of Agricultural Education in reducing Postharvest losses (PHLs) and Food Insecurity in Ogun State, Nigeria". ARJA Volume 2016; pp:1-10

Copyright (c) 2016 Oyediran, Wasiu Oyeleke, Omoare, Ayodeji Motunrayo, This is an open access article distributed under the Creative Commons Attribution License, which permits unrestricted use, distribution, and reproduction in any medium, provided the original work is properly cited. 